\title{
Severity of Septoria Leaf Spot and Sunflower Yield Due to Leaf Wetness Duration
}

\author{
Silvane Isabel Brand ${ }^{1}$, Arno Bernardo Heldwein ${ }^{2}$, Sidinei Zwick Radons ${ }^{3}$, Jocélia Rosa da Silva ${ }^{2}$ \\ \& Andressa Janaína Puhl ${ }^{2}$ \\ ${ }^{1}$ Departament of Biosystems Engineering, University of São Paulo, Piracicaba, SP, Brazil \\ ${ }^{2}$ Department of Crop Science, Federal University of Santa Maria, Santa Maria, RS, Brazil \\ ${ }^{3}$ School of Agronomy, Federal University of Fronteira Sul, Cerro Largo, RS, Brazil \\ Correspondence: Silvane Isabel Brand, School of Agricultural Systems Engineering, University of São Paulo, \\ Piracicaba, SP, Brazil. Tel: 55-19-984-111-427. E-mail: silvanebrand@usp.br
}

$\begin{array}{lcc}\text { Received: June 13, 2018 } & \text { Accepted: July 17, } 2018 & \text { Online Published: September 15, } 2018 \\ \text { doi:10.5539/jas.v10n10p178 } & \text { URL: https://doi.org/10.5539/jas.v10n10p178 }\end{array}$

\begin{abstract}
The objective of this study was to evaluate the effect of leaf wetness on the severity of septoria leaf spot in sunflower. The experiments were performed in two sowing dates in November and January in Santa Maria, RS. Sunflower inoculation was carried out with the Septoria helianthi isolate, with subsequent assessment of disease severity, progress and cypsela yield. The treatments were composed of different periods of $0,8,12,16,20,24$, 28 and 32 hours of artificially applied leaf wetness. Variables influencing the disease were observed during the cycle, such as mean air temperature, mean relative air humidity and daily-accumulated rainfall. The greater the leaf wetness the greater the severity and the area under the disease progress curve. Meantime, the healthy leaf area duration has an inverse relation with leaf wetness duration. The yield also decreases with greater leaf wetness duration and the yield reduction reaches $100 \%$ in the plants exposed to the longer leaf wetness periods.
\end{abstract}

Keywords: Helianthus annuus, Septoria helianthi, yield reduction

\section{Introduction}

The sunflower is a crop expanding in the national and world agricultural scenario mainly due to the increasing demand of oil (Backes et al., 2008). Moreover, the crop can also be used in human diets and animal feeding (Porto et al., 2008), and in the cosmetics industry (Moraes \& Paula, 2017). Thus, improving the current low yield levels is important to consolidate the sunflower competitiveness in agribusiness. Low yield is frequently observed due to different adverse factors, which prevent the yield potential expression of the available genotypes. In Brazil, part of this problem emerges from the difficulty in carrying out disease control (Gomes et al., 2008; Leite \& Oliveira, 2015).

In Brazil, septoria leaf spot on sunflower has not been considered with the proper attention, as there is no availability of tolerant genotypes or recommendation of fungicides along with MAPA (Ministry of Agriculture, Livestock and Supply). Air temperature, rainfall and leaf wetness are among the main meteorological variables that affect the development of most fungi (Agrios, 2004; Gillespie \& Sentelhas, 2008; Bosco et al., 2009). Thus, in rainy years with El Niño warm phase (Izumi et al., 2014), septoria leaf spot can cause considerable plant damage because of the increase in inoculum dispersion and leaf wetness, leading to significant yield and profit reduction.

The oil production capacity in different climate and soil conditions makes sunflower cultivation recommended for Rio Grande do Sul (Silva \& Freitas, 2008). However, the humid climate of the southern region exposes the plants to more favorable conditions for disease development, especially those of fungal origin.

In view of the foregoing, the evaluation of the influence of environmental variables on the growth of the septoria leaf spot using quantitative index is necessary. This procedure will allow a technical management of the actions to confront the problem, such as assisting in selecting the sowing dates that result in less exposure to the disease favorable condition. Thus, the objective of this study was to evaluate the progress of septoria leaf spot in sunflower under different leaf wetness duration periods after pathogen inoculation in sunflower plants sown in November and January in the central region of Rio Grande do Sul. 


\section{Material and Methods}

\subsection{Experimental Characterization of the Local}

The experiments were performed in Santa Maria (RS) (latitude: $29^{\circ} 43^{\prime} 23^{\prime \prime}$ S, longitude: $53^{\circ} 43^{\prime} 15^{\prime \prime}$ W and altitude: $95 \mathrm{~m}$ ). According to the Köppen climate classification, the climate of the region is Cfa, characterized as subtropical humid with hot summer (Alvares et al., 2013) and uniformly distributed rainfall in the four seasons of the year (Heldwein et al., 2009). The predominant soil in the experimental area is classified as sandy loam typic Paleudalf.

\subsection{Installing and Conducting Experiments}

The first experiment was sown on November 24, 2015 and the second experiment on January 28, 2016, using the single cross hybrid Altis 99 . The sowing procedure was performed in no-tillage system under oat straw. Spacing of $0.33 \mathrm{~m}$ between plants in the row and $0.7 \mathrm{~m}$ between rows were used, with a plant population of 43,290 plants per hectare. Crop fertilization was carried out based on the soil analysis and the need of the sunflower crop (CQFS-RS/SC, 2004).

The cultural practices were performed according to the proper crop conduction, including weeding, insecticide and fungicide applications (up to the stage of maximum 10 leaves), which occurred when necessary using a backpack manual sprayer. The fungicide recommended by the MAPA was utilized for fungal disease control at the recommended dose for Alternaria helianthi control in sunflower. The active ingredients of azoxystrobin and cyproconazole and systemic mode of action are characteristics of the utilized fungicide. Spraying was performed when there was disease incidence. However, the fungicide application and the residual were observed in order to not interfere in the fungal infection at the inoculation time, following information contained in the fungicide insert.

\subsection{Treatments}

The treatments were composed of eight different periods of artificially applied leaf wetness, as follows: natural leaf wetness ( 0 hours of artificial wetting), 8, 12, 16, 20, 24, 28 and 32 hours of artificial leaf wetness, applied in addition to the naturally occurring leaf wetness.

The experiments were organized in a completely randomized design with eight treatments and four replicates, totaling 32 experimental units for each sowing date. Each plot was composed of 4 plant rows with $5 \mathrm{~m}$ long, totaling an area of $14.0 \mathrm{~m}^{2}$, with an useful area of $8.4 \mathrm{~m}^{2}$ per plot.

In order to account for the natural leaf wetness in the experiment, we considered that dew formation occurred when the relative air humidity was equal or above $87 \%$ (Kruit et al., 2004). The artificial increasing of the leaf wetness period consisted of an automated micro-sprinkler system located in the central row of the plot and the second or third row was evaluated in each experimental plot.

\subsection{Isolation, Multiplication and Application of the Pathogen}

The fungus was isolated from the sunflower leaves obtained in a field in the region of the Missions of Rio Grande do Sul. Fungus isolation was performed by the direct method followed by monosporic (Alfenas \& Ferreira, 2007) in a specific semolina medium.

For the inoculation, the colony forming units (CFU) were counted (Alfenas \& Ferreira, 2007) using a Neubauer chamber. The concentration of $1 \times 10^{5} \mathrm{CFU} \mathrm{mL} \mathrm{mL}^{-1}$ was used for the inoculation of the septoria leaf spot on sunflower (Ortiz et al., 2016).

In both experiments, field inoculation occurred at around 6 p.m. (Brasília time) after a rainfall. Moreover, the source of inoculum presented about 35 days after its insertion in both inoculations. The inoculation was performed with the aid of a sprayer, which in both experiments occurred in the crop reproductive stage. In experiment 1, with sowing in November, the inoculation occurred in the R4 stage on January 26, 2016. Meanwhile in experiment 2, sown in January, the inoculation was performed in the R1 stage on March 11, 2016.

\subsection{Phenometric Variables}

The maximum leaf width (L) was determined during the cycle to calculate the leaf area (LA) (Maldaner et al., 2009). Subsequently, the leaf area index (LAI) was calculated.

\subsection{Disease Progress}

Severity assessments were performed every two days after the first symptoms were visualized after inoculation, which is a direct method of symptom assessment. The observed severity values were determined from the comparison with the diagrammatic scale proposed by Leite and Amorim (2002b). 
The healthy leaf area duration (HLAD) and the area under the disease progress curve (AUDPC) were calculated based on the mean data of severity observed. The AUDPC was calculated based on the observed severity and the period between two consecutive assessments. The HLAD data were obtained through the observed severity and the leaf area index, integrating the healthy leaf area duration. The AUDPC and HLAD were calculated as described by Campbell and Madden (1990).

\subsection{Meteorological Variables}

The meteorological variables were obtained from the automatic meteorological station belonging to the National Institute of Meteorology (INMET), located $90 \mathrm{~m}$ from the experiment. For the mean daily air temperature $\left({ }^{\circ} \mathrm{C}\right)$ calculation, the mean of the instantaneous air temperature obtained in the 24 hour readings was performed. The daily mean relative air humidity (\%) was calculated based on the mean calculation of the instantaneous relative air humidity in the same way as for the temperature. The rainfall was obtained by summing the rainfall of each hour of the day, obtaining the daily-accumulated rainfall $(\mathrm{mm})$.

\subsection{Harvest}

The harvest of heads was performed when the plants reached the R8 stage. Thereafter, the grains were weighed and the moisture was measured. Moreover, the weight was adjusted to the moisture of $13 \%$ and extrapolated to hectares in order to obtain the productivity in $\mathrm{kg} \mathrm{ha}^{-1}$.

\subsection{Analysis of Results}

Data of observed severity, AUDPC, HLAD and yield were submitted to verification of fulfillment of the statistical assumptions and then to regression analysis. The Sisvar ${ }^{\circledR}$ software (Ferreira, 2011) was utilized for statistical analysis, such as mathematical function adjustment. After adjusting the equation, the statistical parameters coefficient of determination $\left(\mathrm{R}^{2}\right)$ and Root Mean Square Error (RMSE) were evaluated.

\section{Results}

The meteorological variables, daily mean air temperature, daily mean relative air humidity and daily-accumulated rainfall are the main factors that influence the development of septoria leaf spot (Agrios, 2004). Moreover, the values and variation of these meteorological variables were different for the experiments in November and January (Figure 1) (See Figure A1 for illustration of picture and checks the difference of two experiments).



Figure 1. Observed severity (SEV) of septoria leaf spot in sunflower under natural leaf wetness, daily mean air temperature (Tmed), daily mean relative air humidity (UR) and daily-accumulated rainfall (Prec) obtained in the automatic meteorological station of Santa Maria-RS in the days after inoculation (DAI) performed in the R4 and

R1 stages at 51 and 38 days after plant emergence respectively in the experiments sown in November (A) and January (B)

In the November experiment, the severity exhibited a faster growth in the period of 25 days after inoculation (DAI) after frequent rainfall events. At the end of the period of evaluation of the severity after inoculation, the rainfall allied to milder temperatures promoted greater disease growth, with a rapid increase in severity, reaching $100 \%$ at 50 days. Throughout the disease growth period, the daily mean air temperature varied from $19.1{ }^{\circ} \mathrm{C}$ to $28.7^{\circ} \mathrm{C}$. Furthermore, the temperature became milder after $30 \mathrm{DAI}$, which also may have contributed to the fast 
disease development. The daily mean relative air humidity ranged from $62 \%$ to $96.7 \%$, being higher until 31 DAI and with larger oscillations after this period. Rainfall was of $261.2 \mathrm{~mm}$ during the 50 days of severity evaluation after inoculation, being concentrated until 30 DAI, with $195.8 \mathrm{~mm}$. This may have contributed to accelerate the disease dispersion and increased severity. The most favorable conditions during the 30 DAI period promoted a faster disease growth due to the milder air temperature associated with greater rainfall and greater relative air humidity.

The results of the January experiment exhibited an accelerated increase in severity due to higher rainfall, which totaled $323.6 \mathrm{~mm}$ after inoculation up to the end of the cycle and $242.2 \mathrm{~mm}$ occurred up to 30 DAI. The daily mean air temperature ranged from $8.6^{\circ} \mathrm{C}$ to $30.9^{\circ} \mathrm{C}$. Moreover, milder temperatures were observed until 30 DAI, ranging from $18.9{ }^{\circ} \mathrm{C}$ to $28.6^{\circ} \mathrm{C}$. Mean air humidity ranged from $58.5 \%$ to $99.8 \%$ during the $50 \mathrm{DAI}$, with lower variation up to $30 \mathrm{DAI}$, with values ranging from $66.3 \%$ to $99.7 \%$, resulting in greater mean of relative air temperature. Meanwhile, there was a reduction of the relative air humidity to minimum values of $58.5 \%$ from 34 to $40 \mathrm{DAI}$ and in the last days of assessments, which were interspersed by a period with high relative air humidity, with a maximum of $97.5 \%$. In summary, mean air temperature, mean relative air humidity and accumulated rainfall were favorable in the 30 days post inoculation and promoted the highest growth of septoria leaf spot during this period. After $30 \mathrm{DAI}$, with severity close to $65 \%$, the temperature condition seems to be more important for disease expansion due to the accelerated injury growth in the plant tissues and less dependent of leaf wetness. Figure 1B shows that about 5 days after the three periods with high air temperature (occurring from 18/Mar/2016 to 23/Mar/2016, 04/April/2016 to 11/April/2016 and 16/April/2016 to 21/April/2016), three short periods occurred respectively with increased observed severity rate as expression of injured tissue from the previous days. This observation allows inferring that under high inoculum pressure as verified in January, the disease advance depends more on the injury growth and less on new infections once the tissue has already been infected.

The mean severity in the different treatments was lower in the November experiment than in the January experiment (Figure 2). In both experiments, the severity showed a linear increase trend with increased leaf wetness period (Figure 2).

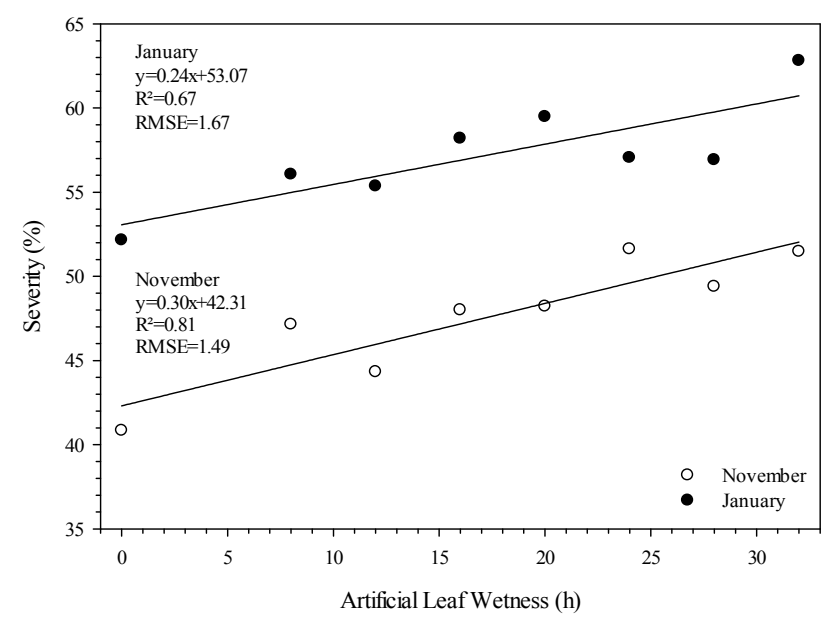

Figure 2. Observed mean severity of septoria leaf spot in sunflower and its relation with increased artificial leaf wetness duration from 0 to 32 hours from the pathogen inoculation performed in R4 and R1 plant stages in the experiments sown in November and January in Santa Maria, RS

In the November experiment, the severity in the natural leaf wetness (zero hours of additional artificial leaf wetness) exhibited the lowest mean of all period (41\%) and the severity increased as artificial leaf wetness increased. Thus, the severity mean was greater in the leaf wetness duration of $32 \mathrm{~h}$, with an approximate increase of $10 \%$ in relation to the natural condition. The trend line adjustment resulted in a coefficient of determination $\left(\mathrm{R}^{2}\right)$ of 0.81 and RMSE of $1.49 \%$.

In the January experiment, the severity observed at the different durations of additional leaf wetness was greater (Figure 2), since there was greater inoculum pressure remaining from the first experiment in the adjacent area. 
However, the severity presented the same trend: the natural leaf wetness presented the lowest severity $(\approx 52 \%)$ and severity increased with increased artificial leaf wetness duration until the maximum leaf wetness of 32 hours $(\approx 62 \%)$. Meantime, the statistical parameters exhibited lower values, with $\mathrm{R}^{2}$ of 0.67 and RMSE of $1.67 \%$.

The AUDPC presented linear relation in response to different periods of additional leaf wetness (Figure 3 ). Thereby for the November experiment, the lowest value of artificial leaf wetness $(0 \mathrm{~h})$, i.e., natural leaf wetness, presented the lowest AUDPC value. Moreover, the trend points to an increase in AUDPC to values around 2,100 with increased leaf wetness, with maximum values reached by artificial leaf wetness of 24, 28 and 32 hours. On the other hand, AUDPC values were greater in the January experiment than in November, but the growing linear trend remained with increased artificial leaf wetness. The maximum value was reached with additional leaf wetness of 32 hours (AUDPC $=3,073$ ), about 545 units greater than with natural leaf wetness ( 0 hours).

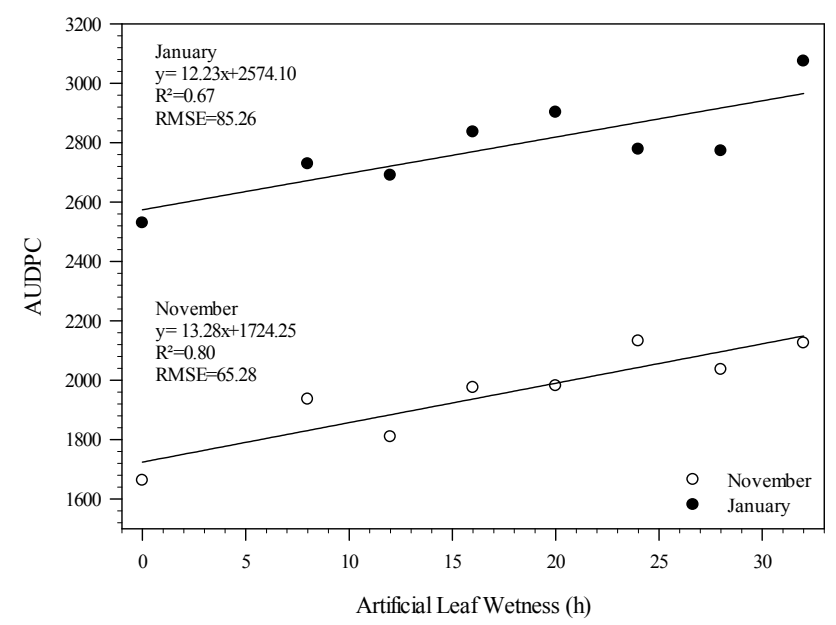

Figure 3. Area under the disease progression curve (AUDPC) of septoria leaf spot in sunflower and its relation with increased artificial leaf wetness duration from 0 to 32 hours in the experiments sown in November and January in Santa Maria, RS

The highest coefficient of determination was found in the November experiment $\left(\mathrm{R}^{2}=0.80\right)$. The $\mathrm{R}^{2}$ value $(0.67)$ was lower in the January experiment because of the condition of greater rainfall and relative humidity, which promoted greater natural leaf wetness in all treatments. Therefore, the different treatments presented a more favorable condition to increase disease progression and the AUDPC. In this way, the condition of greater rainfall and wetness duration in the aerial part explains the higher AUDPC found in the January experiment in comparison to November. In addition, both experiments were located side by side. Thus, the January experiment received an additional inoculum source, which probably contributed to an early and rapid development of the septoria leaf spot. This fact eventually affected the AUDPC and the disease severity, which presented smaller variation between the different leaf wetness treatments.

The HLAD values in the different levels of leaf wetness applied for the experiments of November and January (Figure 4) also presented a linear trend but in a negative relation. Thus, greater artificial leaf wetness periods resulted in lower HLAD values in both experiments. In the November experiment, the highest HLAD value was found with natural leaf wetness $(0 \mathrm{~h})$, presenting about 46 days. Moreover, lower values closer to 40 days were observed with increased leaf wetness periods, with smaller values found in the additional leaf wetness of 24,28 and 32 hours. In the January experiment, the highest HLAD was observed in the natural leaf wetness ( 0 hours), with value close to 55 days. The HLAD decreased as leaf wetness duration increased, with the lowest value found in leaf wetness duration of 32 hours (46 days). Therefore, a 32-hour increase in leaf wetness after inoculation resulted in a HLAD decrease of six to nine days. The same trend observed for AUDPC (Figure 3) was also observed for HLAD due to greater rainfall and greater relative air humidity, promoting a similar behavior in the different leaf wetness periods in the January experiment. 


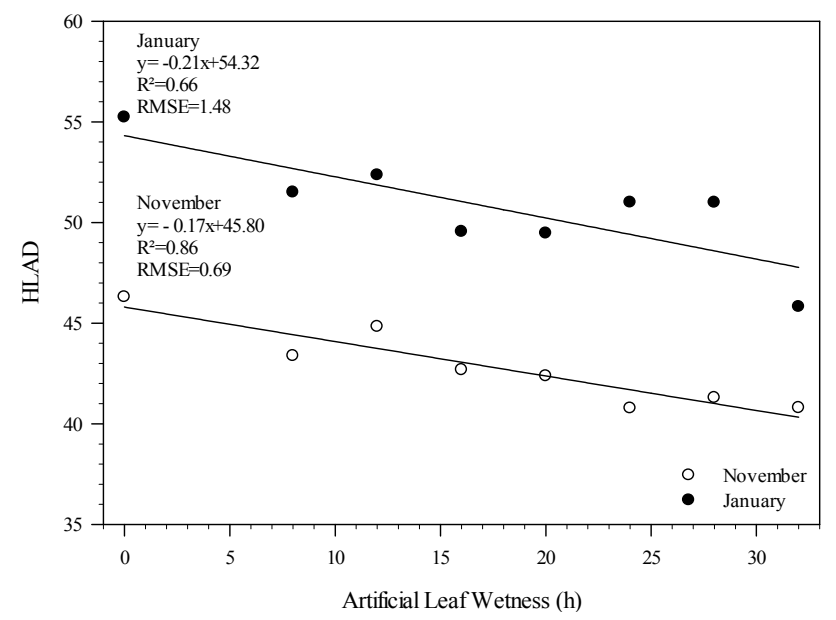

Figure 4. Healthy leaf area duration (HLAD) of septoria leaf spot in sunflower and its relation with increased artificial leaf wetness duration from 0 to 32 hours in the experiments sown in November and January in Santa Maria, RS

Thus, even though HLAD presented a linear trend in both experiments, the highest coefficient of determination was found in the November experiment $\left(\mathrm{R}^{2}=0.86\right)$, while a lower $\mathrm{R}^{2}$ value of 0.66 was obtained in the January experiment.

Regarding yield, significant differences were observed only in the January experiment. The negative exponential equation for yield in the January experiment (Figure 5) indicates that the natural leaf wetness was the treatment with greater yield, with a yield decrease trend in increased leaf wetness duration. Regarding the statistical variables, the coefficient of determination was of 0.90 for the January experiment. The RMSE was of 5.49, indicating an equation estimate error of about $5.5 \mathrm{~kg} \mathrm{ha}^{-1}$ in relation to the observed values.

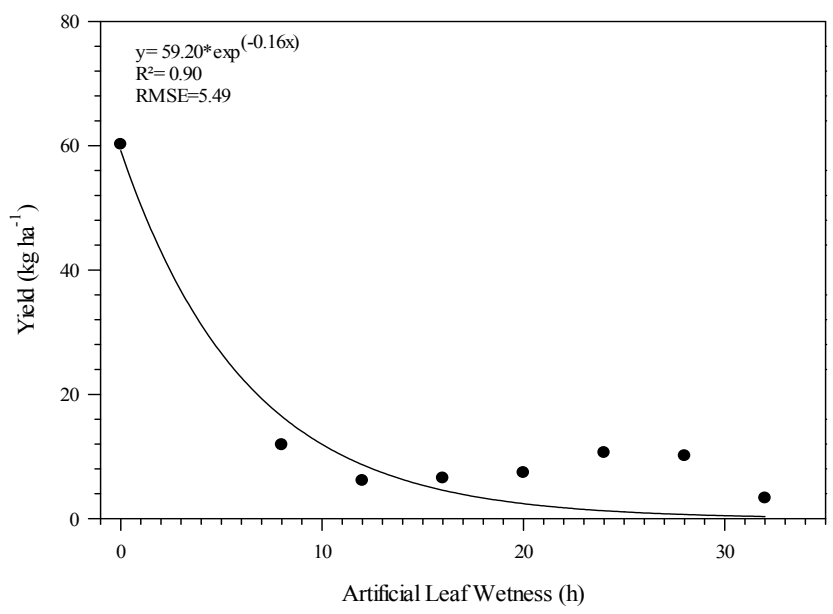

Figure 5. Yield of sunflower cypselas with artificial leaf wetness after inoculation of Septoria helianthi in sunflower and its relation with artificial leaf wetness duration between 0 and 32 hours in an experiment sown in January in Santa Maria, RS

\section{Discussion}

Rainfall is one of the factors that most act on pathogen dispersion, enabling the beginning of a new cycle in a larger area and accelerating disease spreading (Agrios, 2004). Sentelhas et al. (1996), Loose et al. (2012) and Maldaner et al. (2015) also verified that the condition of greater rainfall favors the septoria leaf spot in sunflower. Thus, we also observed an accelerated growth of the septoria leaf spot in a greater rainfall condition (Figure 1), 
which conditioned the increase in the observed disease severity. Thus, the greatest disease growth in the January experiment compared to November is explained in part by the higher rainfall in the post-inoculation phase. Besides disease growth, precipitation promotes greater pathogen dispersion and an accentuated inoculum expansion, allowing new infected areas.

Air temperature has different effects on the development of pathogens. The fungus of Septoria genus develops in a wide range of air temperature, from 10 to $27{ }^{\circ} \mathrm{C}$ (Agrios, 2004), which in general will not influence with the same significance as the leaf wetness period in the occurrence of infection. In both experiments, mean air temperature remained at the ideal range for fungus development. However, conditions of milder temperature were observed in the last 20 days in the November experiment, which favored the pathogen in relation to the mean air temperature. The temperature is a mechanism used by the tropical pathogens, which have the injury growth as an important component that promotes increased severity, besides the new infections as a conditioner of increased severity (Bergamin Filho \& Amorim, 2001).

The air humidity is one of the factors conditioning leaf wetness (Sentelhas et al., 2008) and favoring the growth of pathogen infections in plants. Therefore, as the air humidity was greater in the January experiment than in November, it contributed favoring septoria leaf spot infection and increased observed severity. Even in a natural wetting condition, septoria leaf spot was more benefited in the January experiment than in November because of the increased chance of new infections.

In all treatments of additional artificial wetting after inoculation, the severity was greater in the lower third of the plant, decreasing to the middle and upper third, corroborating with the result found by Amabile et al. (2002) with alternaria leaf blight in sunflower. Maximum severity of $100 \%$ was reached in the lower third with increased leaf wetness by nebulization before than in the natural leaf wetness condition in both experiments. There is less energy and steam exchange in the lower third of the plant, with longer leaf wetness periods due to slower drying. The wetting is greater in the portion closer to the ground compared to the upper third because of the contribution of higher moisture at the soil surface due to the relatively frequent rainfall occurred in the experiments along with the applied artificial wetting. Thus, the air humidity becomes greater in the lower third, decreasing as the height increases from the ground level (Sentelhas et al., 2005). The evaporation or drying time is variable according to the crop, plant architecture and air renewal rate next to the leaves, being generally greater in the lower third than in the upper third. According to Wittich (1995), the upper third is more exposed to the exchange medium. The mass exchanges are larger due to higher wind velocity and the radiant energy balance is greater during daytime period, resulting in greater direct effect of the energy availability, balance of radiation and leaf energy for the faster evaporation process in the upper third than in the others. Thus, this balance is progressively altered with lower energy availability as its determination deepens in the plant canopy towards the ground, causing prolonged leaf wetness closer to the soil after rainfall or irrigation and smaller leaf wetness on the most exposed surface of the canopy, i.e. crop summit.

The variable that influenced the increase in severity was the additional artificial leaf wetness duration immediately after the pathogen distribution on the plants in the area as the air temperature and rainfall conditions were the same for all treatments. Sentelhas et al. (1996), Loose et al. (2012) and Maldaner et al. (2015) also found a correlation between leaf wetness and the alternaria leaf blight, with increased disease severity in greater leaf wetness condition. Furthermore, Leite and Amorim (2002a) observed an increase in the lesion severity and density of alternaria leaf blight in sunflower with increased leaf wetness duration in a controlled environment. The greater severity observed in the experiments of both sowing dates in this study differ in terms of months from the results found by Loose et al. (2012), which analyzed an El Niño year and verified greater severity for the months of October and November and lower in the months of December and January. However, there was greater rainfall and milder air temperature in October and November than in December and January due to the El Niño effect on their experiment. Meantime in this study, rainfall and relative humidity were higher in the January experiment, which favored the disease severity of septoria leaf spot in this experiment, besides the greater inoculum pressure remaining from the previous sunflower crop in the spring in the area adjacent to the January experiment.

According to Agrios (2004), dew is one of the factors that most influences the development of certain pathogens, causing greater growth and sporulation and contributing to the infectious process. Therefore, the greater severity found in the greater leaf wetness periods in the different experiments corroborates this assertion.

According to Loose et al. (2012) in a year of El Niño, the highest AUDPC occurred in the months of October and November, the period of greatest positive effect of the phenomena on precipitation in Rio Grande do Sul state, being lower in December and January. These results diverge from those found in our study, with lower AUDPC 
in the November experiment in relation to January. This fact is probably due to higher inoculum pressure in January, as well as to rainfall during the crop cycle that favored greater pathogen dispersion. Thus, the greater disease severity in the January experiment promoted a greater AUDPC in the same experiment. These results corroborate with those found by Leite et al. (2006) for the alternaria leaf blight in sunflower.

In an experiment performed in Santa Maria, Rio Grande do Sul in an El Niño year, the highest HLAD was found in December and the lowest value was obtained in October, since January did not differ from December and November did not differ from October (Loose et al., 2012). The highest HLAD in December and January obtained by Loose et al. (2012) did not differ from the results obtained in this study. The greater leaf area obtained in the January experiment causes a longer healthy leaf area duration, even with greater disease severity. This is observed because the evaluations started at the inoculation day, resulting in lower severity values at the beginning, besides a greater number of evaluations. Thus, there was an HLAD increase in the January experiment when compared to November.

The yield observed in the experiments was lower than the mean yield found in commercial cultivation, with mean yield of growing regions of $1,271 \mathrm{~kg} \mathrm{ha}^{-1}$ in the last agricultural year (CONAB, 2016). In this study, the sunflower yield reduction was about $95 \%$ in relation to the mean yield, under conditions of natural leaf wetness and mean severity of $52 \%$. This resulted in decreased healthy leaf area in the plant reproductive stages, which affected the filling of cypselas and yield. In the January experiment, the heads exhibited small diameter and some heads did not developed cypselas due to the high disease severity condition. This experiment had more favorable conditions to the disease, greater inoculum pressure and the inoculation was performed at the beginning of the reproductive period (R1). Meantime, the inoculation was performed in the R4 stage in the November experiment. This indicates the potential damage of the septoria leaf spot on sunflower yield under more severe conditions.

Thus, the disease did not compromise head and grain development in November as severely as in January. Although there was no statistical difference in relation to the different leaf wetness periods and yield, it promoted a reduction of about $70 \%$ in relation to the sunflower mean yield found by CONAB (2016). Thus, disease control should be adopted in order to not affect the reproductive phase. Expressive sunflower yield reduction can occur in this phase, being more expressive with disease occurrence at the beginning of the reproductive phase.

\section{Conclusions}

The increase of leaf wetness causes an increase in septoria leaf spot severity, with greatest severity in the experiment sown in January.

The area under the disease progress curve (AUDPC) increases with increasing leaf wetness duration. The AUDPC was greater in the January experiment when compared to the November sunflower crop.

The healthy leaf area duration decreased with increased leaf wetness duration, with greater values in the January experiment than in November.

In sunflower plants inoculated with Septoria helianthi in the R1 and R4 stage at 51 and 38 days after emergence, the increase in severity caused a decrease in sunflower yield respectively of $95 \%$ and $70 \%$ in the natural leaf wetness condition.

\section{Acknowledgements}

We thank the Coordination for the Improvement of Higher Education Personnel-CAPES for granting scholarships and the National Council for Scientific and Technological Development (CNPq) for the grants of productivity research and scientific initiation.

\section{References}

Agrios, G. N. (2004). Plant Diseases caused by fungi. Plant Pathology (5th ed., pp. 460-463). San Diego: Academic Press.

Alfenas, A. C., \& Ferreira, F. A. (2007). Inoculação de Fungos Fitopatogênicos. In A. C. Alfenas, \& R. G. Mafia (Eds.), Métodos em fitopatologia (pp. 117-137). Viçosa: Editora da UFV.

Alvares, C. A., Stape, J. L., Sentelhas, P. C., De Moraes, G., Leonardo, J., \& Sparovek, G. (2013). Köppen's climate classification map for Brazil. Meteorologische Zeitschrift, 22, 711-728. https://doi.org/10.1127/ 0941-2948/2013/0507 
Amabile, R. F., Vasconcelos, C. M., \& Gomes, A. C. (2002). Severidade da mancha-de-alternária em cultivares de girassol na região do Cerrado do Distrito Federal. Pesquisa Agropecuária Brasileira, 37, $251-257$. https://doi.org/10.1590/S0100-204X2002000300004

Backes, R. L., De Souza, A. M., Junior, A. A. B., Gallotti, G. J. M., \& Bavaresco, A. (2008). Desempenho de cultivares de girassol em duas épocas de plantio de safrinha no planalto norte catarinense. Scientia Agraria, 9, 041-048. https://doi.org/10.5380/rsa.v9i1.10131

Bergamin Filho, A., \& Amorim, L. (2001). Epidemiologia comparativa entre os patossistemas temperado e tropical: Conseqüências para a resistência a fungicidas. Fitopatologia Brasileira, 26, 119-127. https://doi.org/10.1590/S0100-41582001000200001

Bosco, L. C., Heldwein, A. B., Lucas, D. D. P., Trentin, G., Grimm, E. L., \& Loose, L. H. (2009). Sistema de previsão de ocorrência de requeima em clones de batata suscetíveis e resistentes. Ciência Rural, 39, 1024-1031. https://doi.org/10.1590/S0103-84782009005000050

Campblell, C. L., \& Madden, L. V. (1990). Forecasting plant diseases. Introduction to plant disease epidemiology (pp. 423-452). New York: John Wiley \& Sons.

CONAB (Companhia Nacional De Abastecimento). (2016). Séries históricas. Retrieved from http://www.conab.gov.br/conteudos.php? $\mathrm{a}=1252 \& \&$ Pagina_objcmsconteudos=3\#A_objcmsconteudos

CQFS-RS/SC (Comissão De Química e Fertilidade do Solo). (2004). Manual de adubação e calagem para os Estados do Rio Grande do Sul e Santa Catarina. Porto Alegre: Sociedade Brasileira de Ciência do Solo-Núcleo Regional Sul.

Ferreira, D. F. (2011). Sisvar: a computer statistical analysis system. Ciência e Agrotecnologia, 35, $1039-1042$. https://doi.org/10.1590/S1413-70542011000600001

Gillespie, T. J., \& Sentelhas, P. C. (2008). Agrometeorology and plant disease management: A happy marriage. Scientia Agricola, 65, 71-75. https://doi.org/10.1590/S0103-90162008000700012

Gomes, D. P., Campos Leite, R. M. V. B., Moraes, M. F. H., \& Kronka, A. Z. (2008). Sanidade de sementes de girassol provenientes de três municípios do estado do Maranhão. Revista Caatinga, 21, 55-63. Retrieved from http://www.redalyc.org/articulo.oa?id=237117576008

Heldwein, A. B., Buriol, G. A., \& Streck, N. A. (2009). O clima de Santa Maria. Ciência e Ambiente, 43-58.

Izumi, T., Luo, J. J., Challinor, A. J., Sakurai, G., Yokozawa, M., Sakuma, H., \& Yamagata, T. (2014). Impacts of El Niño Southern Oscillation on the global yields of major crops. Nature Communications, 5, 1-7. https://doi.org/10.1038/ncomms4712

Kruit, R. J. W., Van Pul, A. J., Jacobs, A. F. G., \& Heusinkveld, B. G. (2004). Comparison between four methods to estimate leaf wetness duration caused by dew on grassland. Conference on Agricultural and Forest Meteorology, American Meteorological Society, Vancouver.

Leite, R. M. V. B. C., \& Amorim, L. (2002a). Influência da temperatura e do molhamento foliar no monociclo da mancha de alternária em girassol. Fitopatologia Brasileira, 27, 193-200, https://doi.org/10.1590/S0100-41 582002000200012

Leite, R. M. V. B. C., \& Amorim, L. (2002b). Elaboração e validação de escala diagramática para mancha de alternária em girassol. Summa Phytopathologica, 28, 14-19. Retrieved from http://cat.inist.fr/?aModele= afficheN\&cpsidt $=13758187$

Leite, R. M. V. B. C., Amorim, L., \& Bergamin Filho, A. (2006). Relationships of disease and leaf area variables with yield in the Alternaria helianthi-sunflower pathosystem. Plant Pathology, 55, 73-81. https://doi.org/ 10.1111/j.1365-3059.2005.01313.x

Leite, R. M. V. B. D., \& Oliveira, M. C. N. D. (2015). Grouping sunflower genotypes for yield, oil content, and reaction to Alternaria leaf spot using GGE biplot. Pesquisa Agropecuária Brasileira, 50, 649-657. https://doi.org/10.1590/S0100-204X2015000800003

Loose, L. H., Heldwein, A. B., Maldaner, I. C., Lucas, D. D. P., Hinnah, F. D., \& Bortoluzzi, M. P. (2012). Severidade de ocorrência das manchas de alternária e septoriose em girassol semeado em diferentes épocas no Rio Grande do Sul. Bragantia, 71, 282-289. https://doi.org/10.1590/S0006-87052012005000012

Maldaner, I. C., Heldwein, A. B., Bortoluzzi, M. P., Loose, L. H., Lucas, D. D., \& Silva, J. R. D. (2015). Irrigation and fungicide application on disease occurrence and yield of early and late sown sunflower. Revista 
Brasileira de Engenharia Agrícola e Ambiental, 19, 630-635. https://doi.org/10.1590/S1415-43662 011000200003

Maldaner, I. C., Heldwein, A. B., Loose, L. H., Lucas, D. D. P., Guse, F. I., \& Bortoluzzi, M. P. (2009). Modelos de determinação não-destrutiva da área foliar em girassol. Ciência Rural, 39, 1356-1361. https://doi.org/ $10.1590 / \mathrm{S} 0103-84782009000500008$

Moraes, D. C., \& Paula, D. (2013). Processamento do óleo de girassol como estratégia para a produção de cosméticos orgânicos, Eclética Química, 38, 187-201. https://doi.org/10.26850/1678-4618eqj.v38.1.2013. p187-201

Ortiz, F., Rodríguez, D., Sanabria, M. E., \& Pineda, J. (2016). Manejo del tizón tardío del celery (Apium graveolens L. var. Dulce) usando extractos vegetales bajo condiciones controladas. Bioagro, 28, 87-94. Retrieved from https://dialnet.unirioja.es/servlet/articulo?codigo=5509127

Porto, W. S., Carvalho, C. G. P. D., Pinto, R. J. B., Oliveira, M. F. D., \& Oliveira, A. C. B. D. (2008). Evaluation of sunflower cultivars for central Brazil. Scientia Agricola, 65, 139-144. https://doi.org/10.1590/S0103-90 162008000200005

Sentelhas, P. C., Dalla Marta, A., Orlandini, S., Santos, E. A., Gillespie, T. J., \& Gleason, M. L. (2008). Adequação da umidade relativa como estimador da duração da humidade da folha. Meteorologia Agrícola e Florestal, 148, 392-400. https://doi.org/10.1016/j.agrformet.2007.09.011

Sentelhas, P. C., Gillespie, T. J., Batzer, J. C., Gleason, M. L., Monteiro, J. E. B., Pezzopane, J. R. M., \& Pedro, M. J. (2005). Spatial variability of leaf wetness duration in different crop canopies. International Journal of Biometeorology, 49, 363-370. https://doi.org/10.1007/s00484-005-0259-1

Sentelhas, P. C., Pezzopane, J. R. M., Ungaro, M. R. G., Moraes, S. A., \& Dudienas, C. (1996). Aspectos climáticos relacionados à ocorrência da mancha de alternária em cultivares de girassol. Fitopatologia Brasileira, 21, 464-469.

Silva, P. R. F., \& Freitas, F. S. (2008). Biodiesel: o ônus e o bônus de produzir combustível. Ciência Rural, 38, 843- 851. https://doi.org/10.1590/S0103-84782008000300044

Wittich, K. P. (1995). Algumas observações sobre a duração do orvalho no topo de um pomar. Meteorologia Agrícola e Florestal, 72, 167-180. https://doi.org/10.1016/0168-1923(94)02170-O 


\section{Appedix A}

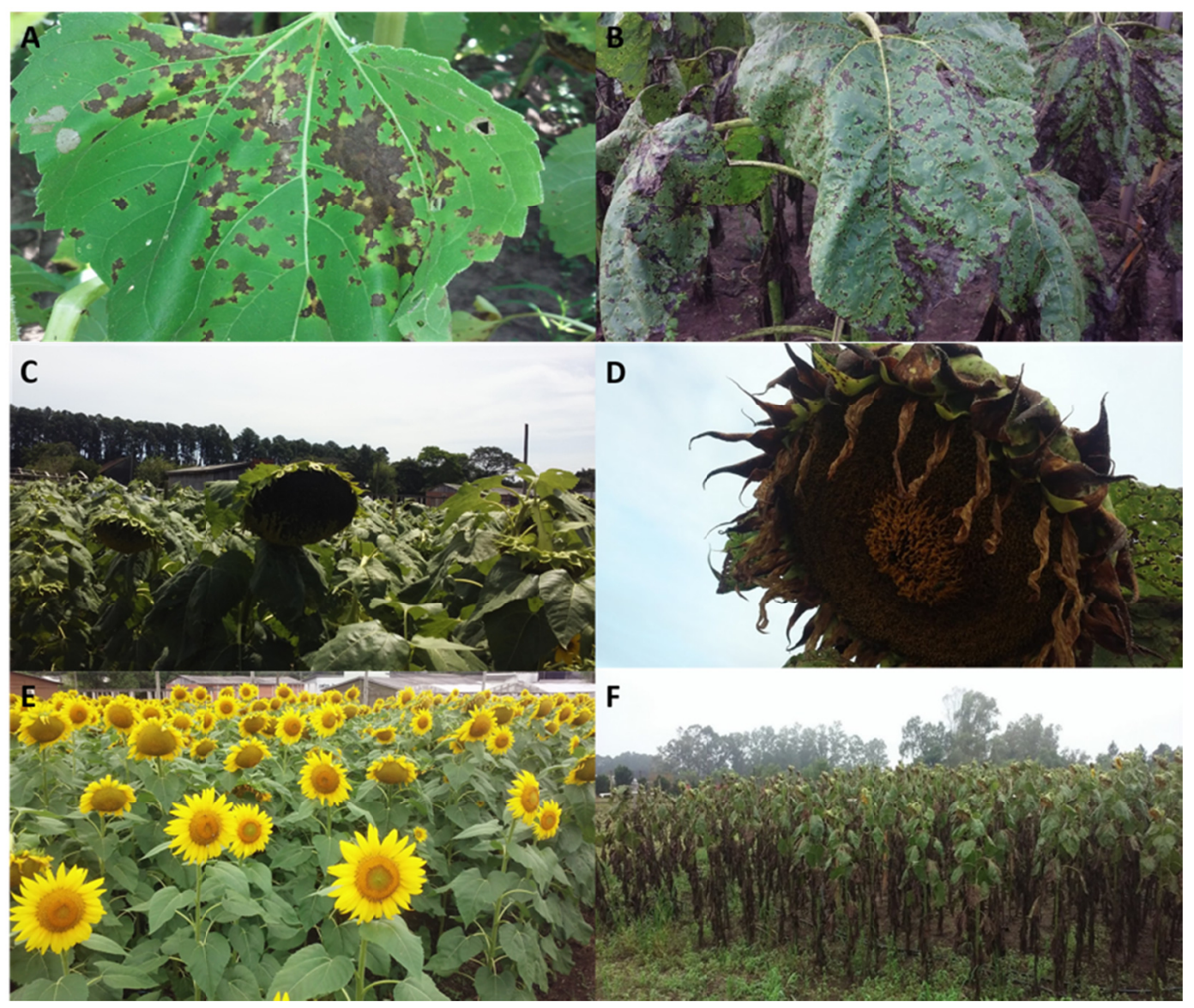

Figure A1. Overview of sunflower leaves, sunflower heads and view of experiment of in the experiment of sunflower of November (A, C and E) and January (B, D and F)

\section{Copyrights}

Copyright for this article is retained by the author (s), with first publication rights granted to the journal.

This is an open-access article distributed under the terms and conditions of the Creative Commons Attribution license (http://creativecommons.org/licenses/by/4.0/). 